\title{
Performance of Paddy Variety Gangavathi Sona under Kabini Command Area of Chamarajanagara District, Karnataka, India
}

\author{
G. S. Yogesh*, C. M. Sunil, A. B. Mohankumar, Chandrakala Hanagi, \\ H. P. Rajath, and P. S. Abhishek \\ ICAR-Krishi Vigyan Kendra, Chamarajanagara District, UAS, \\ GKVK, Bengaluru Karnataka, India \\ *Corresponding author
}

\section{Keywords}

Gangavathi Sona, Salt affected soil, Technology gap, Extension gap

Article Info

Accepted:

07 October 2020 Available Online: 10 November 2020

\section{A B S T R A C T}

Paddy is a major cereal crop of India and Karnataka. In Chamarajanagara district, majority of it is grown under Kabini command area covering Yalandur, Kollegala and Chamarajanagara taluks. Paddy farmers of the area are cultivating IR 64 variety which is very old, poor yielding under salt affected soil conditions and susceptible to major diseases. In order to enhance the yield at farmers level, a new variety GGV-05-01 (Gangavathi Sona) released by UAS Raichur, a salt tolerant variety, also tolerant to sheath blight and blast diseases was tested in comparison with IR 30864 and Vikas (UAS Bangalore varieties) suitable for salt affected soil and farmers variety IR-64 for three years in the farmers' field. An average maximum yield of $5.41 \mathrm{t} \mathrm{ha}^{-1}$ was obtained with GGV05-01 followed by IR $30864\left(5.12 \mathrm{t} \mathrm{ha}^{-1}\right)$, Vikas $\left(4.75 \mathrm{t} \mathrm{ha}^{-1}\right)$ and IR $64\left(4.56 \mathrm{t} \mathrm{ha}^{-1}\right)$. Similar trend was observed with growth, yield parameters and economics. With this background, the variety GGV-05-01 was upscaled to frontline demonstration. The variety was given to 27 farmers of Irasawadi, Y.K. Mole, Uppinamole and Ambale villages of Chamarajanagara and Yalandur taluk during 2016-17 and 2017-18. IR 64 was considered as a check variety. GGV-05-01 recorded an increased yield of $34.6 \%$ over check. Similar trend was observed with harvest index and BC ratio. During 2018-19, the horizontal expansion was 28.4 ha accounting to $1775 \mathrm{~kg}$ seeds that were supplied by farmers themselves and this variety was endorsed by UAS Bangalore for cultivation in maidan areas of Cauvery command which has enabled good quality seed supply to the paddy growers.

\section{Introduction}

Paddy is a major cereal crop of India accounting to $39.5 \%$ of the total food grain production of the country. It occupies an area of $43.7 \mathrm{~m}$ ha with a production of $112.7 \mathrm{~m} \mathrm{t}$ and a productivity of $2.57 \mathrm{t} \mathrm{ha}^{-1}$. In Karnataka, paddy occupies an area of $0.99 \mathrm{~m}$ ha with a production and productivity $3.02 \mathrm{~m} \mathrm{t}$ and 3.04 $\mathrm{t} \mathrm{ha}^{-1}$, respectively. In Chamarajanagara district, paddy is being cultivated in the command area of Yalandur, Kollegala \& Chamarajanagara taluks with canal and tank irrigation. It is also grown as a borewell irrigated crop in parts of the district. The area under paddy in the district is 13186 ha with a 
production and productivity of 70114 tonnes and $4.78 \mathrm{t} \mathrm{ha}^{-1}$, respectively (1). Paddy in the district is mainly grown in deep, black calcareous soils and deep, alluvial clayey soils (salt affected in patches) which accounts to 36608.19 and 31034.15 hectare, respectively (2).

Majority of the paddy area in the district is under variety IR 64 which is very old and its performance is poor under high $\mathrm{pH}$ soils of the paddy growing area of the district and is susceptible to sheath blight and blast diseases. The district area under paddy is coming down because of the major reason untimely release of water from the dam which has made farmers resort for late planting (August month). Further, the problematic soil in the command area has caused problems for paddy cultivation. In order to reduce further increase in the area under problematic soils better agronomic and soil management practices are required to be adopted.

In this context, KVK intervened to address the above mentioned constraints by conducting training programmes, on farm testings (OFTs), frontline demonstrations (FLDs) and other extension activities with the following objectives include assessment of suitable paddy varieties for salt affected soils and also workout the economics of paddy cultivation under this situation.

\section{Materials and Methods}

Through the participatory rural appraisal approach and farmers-scientist interaction, it was found that the cultivation of old variety susceptible to problematic soils conditions, sheath blight/blast disease, and poor agronomic management practices are the major problems in the command area. The study was conducted by ICAR KVK Chamarajanagara from 2013-14 to 2015-16 at Katnawadi village, Yalandur taluk. The OFTs were taken up in three farmers' field in an area of 0.8 ha for each farmer and each variety was grown in 0.2 ha. The varieties taken up in experiment were IR 64 (local name called by growers is "minilong" - check variety), GGV-05-01 (Gangavathi Sona), IR 30864 and Vikas (source: UAS, Bangalore. suitable for salt affected soil). Gangavathi Sona, a variety released by UAS Raichur for salt affected soils with a yield potential of 7.5 $\mathrm{t} \mathrm{ha}^{-1}$ with salinity tolerance $\left(6.5-8.5 \mathrm{dsm}^{-1}\right)$ and is tolerant to sheath blight, BLB and neck blast.

All other practices remained same as per recommendations of package of practices of UAS Bangalore for improved varieties except for check variety wherein farmer practice was followed (Table 1). The soil was alkaline in reaction with $\mathrm{pH}$ ranging from 8.29 to 8.77 , electrical conductivity 0.315 to $0.729 \mathrm{dSm}^{-1}$, organic carbon 0.28 to $0.51 \%$, available nitrogen 118.2 to $219.5 \mathrm{~kg} \mathrm{ha}^{-1}$, available phosphorus 13.8 to $25.8 \mathrm{~kg} \mathrm{ha}^{-1}$, available potassium 152.8 to $229.1 \mathrm{~kg} \mathrm{ha}^{-1}$ (Table 2). The available zinc was below critical limit (0.45 ppm). Green manure crop Dhaincha was grown and incorporated into the soil at $50 \%$ flowering stage. Based on soil test, Gypsum was applied to the main field two weeks before transplanting. Biofertilizers Azospirillum and PSB @ $2 \mathrm{~kg} \mathrm{ha}^{-1}$ each were broadcasted uniformly in the main field.

Based on soil test results, fertilizer doses were applied to the main field. $50 \%$ nitrogen, full dose of phosphorus and $50 \%$ potassium were applied during transplanting. Remaining $25 \%$ nitrogen was top dressed during tillering and remaining $25 \%$ nitrogen and $50 \%$ potassium were applied during panicle initiation stage. Nurseries were raised during July month and transplanted during August month. Need based insect pest and disease management practices were followed as per the recommendations. 
For FLDs, the variety GGV-05-01 was considered after its satisfied performance under OFT. It was compared with check variety IR 64 during 2016-17 and 2017-18 at Irasawadi, Y.K.Mole, Uppinamole and Ambale villages of Chamarajanagara and Yalandur taluk. Selected paddy growers of the villages were trained regarding improved paddy cultivation practices through on campus and off campus trainings. Some of the technologies like seed treatment and enrichment of manure with biofertilizers and zinc sulphate were introduced to farmers through method demonstrations.

A total of 27 frontline demonstrations each in an area of 0.4 ha were conducted. An adjacent farmer's practice field was considered as control for each demonstration for obtaining the information pertaining to growth and yield performance indicators of the local variety IR 64. Initial soil samples were analysed and the soil was alkaline in nature, low in organic carbon, low to medium in phosphorus and medium in potassium. The average soil test values for OFTs and FLDs are given in table 2.

The information pertaining to growth and yield of paddy were collected from the demonstration plots. The data regarding the farmers' practices followed by the paddy growers of the area were collected for knowing the extension gap, technology gap and technology index by adopting suitable formulae (5).

Extension gap $=$ Demonstration yield - Local check yield

Technology gap = Potential yield Demonstration yield

Technology index $=$ Potential yield Demonstration yield x 100/Potential Yield

\section{Results and Discussion}

\section{OFTs}

For all the three years, variety Gangavathi Sona performed better and recorded a good growth attributes like plant height $(84.2 \mathrm{~cm})$ and number of tillers (24.9) than other three varieties. The check variety IR 64 showed lower plant height $(81.2 \mathrm{~cm})$ and number of tillers (19.6) (Table 3). An 11.2, 7.5 and 18.8 average percent increase in yield over check variety IR 64 was recorded with IR 30864, Vikas and GGV-05-01 varieties, respectively.

This may be attributed to the good yield characteristics like panicle length, test weight and harvest index by the improved varieties. Among improved varieties, GGV-05-01 showed good yield characteristics (panicle length, test weight and harvest index -23.4 $\mathrm{cm}, 24.7 \mathrm{~g}$ and 0.44 , respectively). IR 30864 and Vikas were also found superior than IR 64 in terms of growth and yield characteristics but were lower than GGV-05-01.

The check variety IR-64 recorded lower growth and yield characteristics (plant height $81.2 \mathrm{~cm}$, number of tillers 19.6, panicle length $21 \mathrm{~cm}$, test weight $23.6 \mathrm{~g}$ and harvest index 0.42 ). The straw yields recorded were 6.79 , 6.74, 6.43 and $6.38 \mathrm{t} \mathrm{ha}^{-1}$ for GGV-05-01, IR 30864, Vikas and IR 64 varieties, respectively.

Highest BC ratio (2.19) was obtained with the cultivation of GGV-05-01 variety followed by IR 30864, Vikas and IR 64 (2.0, 1.91 and 1.85, respectively). Similar results were reported wherein GGV-05-01 variety showed $32.6 \%$ higher yield over check variety BPT 5204 in vertisols of Tungabhadra project command area (7). 
Table.1 Details of demonstration and farmer practices

\begin{tabular}{|c|c|c|c|}
\hline $\begin{array}{l}\text { Technology } \\
\text { component }\end{array}$ & Demonstration & Farmers' practice & Gap \\
\hline Variety & GGV-05-01 (Gangavathi Sona) & IR-64 (minilong) & Full gap \\
\hline Nursery & As per recommendation & $\begin{array}{l}\text { Not following recommendation } \\
\text { (Zinc and iron deficiency noticed) }\end{array}$ & Partial gap \\
\hline $\begin{array}{l}\text { Application of } \\
\text { organic manure }\end{array}$ & $10 \mathrm{tha}^{-1}$ & Hardly applied & $>75 \%$ gap \\
\hline Green manuring & $2 \mathrm{t} \mathrm{ha}^{-1}$ & Few farmers follow & $>50 \%$ gap \\
\hline Seed treatment & Tricyclazole $75 \% \mathrm{WP}-3 \mathrm{~g} \mathrm{~kg}^{-1}$ seeds & No & Full gap \\
\hline Biofertilizers & Azospirillum and PSB each @ $2 \mathrm{~kg} \mathrm{ha}^{-1}$ & No & Full gap \\
\hline Fertilizers & $\begin{array}{l}\text { 100:50:50 } \mathrm{kg} \mathrm{NPK} \mathrm{ha}^{-1} \text { (modified recommendations based } \\
\text { on soil test values) Basal - 50:50:25 } \mathrm{kg} \mathrm{ha}^{-1} \text { and two top } \\
\text { dressings ( } 50 \mathrm{~kg} \text { Nitrogen) } \\
\text { Zinc Sulphate @ } 16 \mathrm{~kg} \mathrm{ha}^{-1}\end{array}$ & $\begin{array}{l}\text { DAP - } 5 \text { bags or } 17: 17: 17 \text { - } 5 \text { bags plus } \\
\text { urea } 2 \text { bags during transplanting } \\
\left(91: 115: 0 \mathrm{~kg} \mathrm{NPK} \mathrm{ha}^{-1} \text { or } 88.5: 42.5: 42.5\right. \\
\mathrm{kg} \mathrm{NPK} \mathrm{ha-1)} \\
\text { One top dressing with } 2 \text { bags of urea per } \\
\text { hectare ( } 46 \mathrm{~kg} \text { Nitrogen) } \\
\text { No zinc sulphate application }\end{array}$ & Full gap \\
\hline $\begin{array}{c}\text { Water } \\
\text { management }\end{array}$ & $\begin{array}{l}\text { Flood irrigation to a height of two inches as and when the } \\
\text { water level reduces from } 10 \text { days after transplanting to } 10 \\
\text { days before harvest. Providing drainage. }\end{array}$ & $\begin{array}{c}\text { Irregular - excess flooding and no } \\
\text { drainage facilities }\end{array}$ & Full gap \\
\hline Weeding & Manual weeding & Manual weeding & No gap \\
\hline $\begin{array}{l}\text { Insect and } \\
\text { disease } \\
\text { management }\end{array}$ & $\begin{array}{l}\text { Need based with recommended chemicals } \\
\text { For Yellow stem borer - Chlorpyriphos } 20 \text { EC @ } 2 \mathrm{ml} \mathrm{l}^{-1} \\
\text { For sheath blight - Carbendazim 50 WP @ } 1 \mathrm{~g} \mathrm{l}^{-1}\end{array}$ & $\begin{array}{l}\text { Indiscriminate application } \\
\text { For Yellow stem borer-chlorpyriphos } 20 \\
\text { EC @ } 3-5 \mathrm{ml} \mathrm{l}^{-1} \\
\text { For sheath blight }- \text { not following } \\
\text { management }\end{array}$ & Full gap \\
\hline
\end{tabular}


Table.2 Physico-chemical properties of the soil

\begin{tabular}{|c|l|c|c|c|c|c|c|}
\hline Intervention & Year & $\mathbf{p H}$ & $\begin{array}{c}\mathbf{E . C} . \\
\left(\mathbf{d S m}^{-1}\right)\end{array}$ & $\begin{array}{c}\mathbf{O . C} \\
(\mathbf{\%})\end{array}$ & $\begin{array}{c}\mathbf{N} \\
(\mathbf{k g} / \mathbf{h a})\end{array}$ & $\begin{array}{c}\mathbf{P}_{2} \mathbf{O}_{5} \\
(\mathbf{k g} / \mathbf{h a})\end{array}$ & $\begin{array}{c}\mathbf{K}_{2} \mathbf{O} \\
(\mathbf{k g} / \mathbf{h a})\end{array}$ \\
\hline \multirow{2}{*}{ OFT } & $2013-14$ & 8.59 & 0.525 & 0.28 & 171.5 & 20.8 & 252.8 \\
\hline \multirow{2}{*}{ FLD } & $2014-15$ & 8.62 & 0.411 & 0.42 & 163.5 & 15.2 & 192.0 \\
\hline & $2015-16$ & 8.55 & 0.409 & 0.36 & 122.5 & 23.5 & 176.2 \\
\hline & $2016-17$ & 8.36 & 0.513 & 0.39 & 195.8 & 26.8 & 202.8 \\
\hline & $2017-18$ & 8.71 & 0.592 & 0.30 & 148.3 & 17.5 & 172.5 \\
\hline
\end{tabular}

(Average values. OFT - 3 farmers' field each year. FLD 10 farmers' field during 2016-17 and 17 farmers' field during 2017-18)

Table.3 Growth and yield characteristics of the paddy varieties under on farm testing

\begin{tabular}{|c|c|c|c|c|c|c|c|c|c|}
\hline Variety & Year & $\begin{array}{c}\text { Plant } \\
\text { height } \\
(\mathrm{cm})\end{array}$ & $\begin{array}{l}\text { No. of } \\
\text { tillers }\end{array}$ & $\begin{array}{c}\text { Panicle } \\
\text { length } \\
\text { (cm) }\end{array}$ & $\begin{array}{c}\text { Test } \\
\text { weight } \\
\text { (grams) }\end{array}$ & $\begin{array}{l}\text { Grain } \\
\text { Yield } \\
\text { (t/ha) }\end{array}$ & $\begin{array}{l}\text { Straw } \\
\text { Yield } \\
\text { (t/ha) }\end{array}$ & $\begin{array}{c}\text { Harvest } \\
\text { index }\end{array}$ & $\begin{array}{c}\text { BC } \\
\text { Ratio }\end{array}$ \\
\hline \multirow{3}{*}{$\begin{array}{c}\text { IR-64 } \\
\text { (Check } \\
\text { variety) }\end{array}$} & 2013-14 & 82.8 & 20.2 & 20.4 & 23.8 & 4.72 & 6.51 & 0.42 & 1.92 \\
\hline & 2014-15 & 82.5 & 20.5 & 22 & 23.4 & 4.38 & 6.30 & 0.41 & 1.65 \\
\hline & $2015-16$ & 78.2 & 18.2 & 20.5 & 23.6 & 4.58 & 6.32 & 0.42 & 1.98 \\
\hline \multirow{4}{*}{ IR-30864 } & Average & 81.2 & 19.6 & 21.0 & 23.6 & 4.56 & 6.38 & 0.42 & 1.85 \\
\hline & $2013-14$ & 81.9 & 28.5 & 22.6 & 24.7 & 5.25 & 6.95 & 0.43 & 2.10 \\
\hline & 2014-15 & 83.0 & 22.8 & 22.4 & 24.1 & 4.89 & 7.03 & 0.41 & 1.73 \\
\hline & $2015-16$ & 80.5 & 19.4 & 20.4 & 24.3 & 5.08 & 6.20 & 0.45 & 2.16 \\
\hline \multirow{4}{*}{ Vikas } & Average & 81.8 & 23.6 & 21.8 & 24.4 & 5.12 & 6.74 & 0.43 & 2.00 \\
\hline & $2013-14$ & 80.1 & 23.7 & 22.2 & 23.4 & 4.60 & 6.35 & 0.42 & 1.82 \\
\hline & 2014-15 & 82.1 & 23.2 & 23.1 & 24.2 & 5.02 & 6.65 & 0.43 & 1.85 \\
\hline & $2015-16$ & 80.2 & 19.3 & 21.1 & 23.9 & 4.75 & 6.29 & 0.43 & 2.05 \\
\hline & Average & 80.5 & 22.1 & 22.1 & 23.8 & 4.75 & 6.43 & 0.43 & 1.91 \\
\hline \multirow{3}{*}{$\begin{array}{l}\text { Gangava } \\
\text { thi Sona }\end{array}$} & $2013-14$ & 86.0 & 26.0 & 23.9 & 24.5 & 5.08 & 6.46 & 0.44 & 2.01 \\
\hline & 2014-15 & 84.9 & 26.3 & 24.2 & 24.7 & 5.40 & 7.15 & 0.43 & 2.07 \\
\hline & $2015-16$ & 81.8 & 22.5 & 22.2 & 24.8 & 5.75 & 6.75 & 0.46 & 2.48 \\
\hline & Average & 84.2 & 24.9 & 23.4 & 24.7 & 5.41 & 6.79 & 0.44 & 2.19 \\
\hline
\end{tabular}

Table.4 Growth and yield characteristics of the paddy varieties under frontline demonstrations

\begin{tabular}{|c|c|c|c|c|c|c|c|c|}
\hline Variety & Year & $\begin{array}{c}\text { Plant } \\
\text { height }\end{array}$ & $\begin{array}{c}\text { No. of } \\
\text { tillers }\end{array}$ & $\begin{array}{c}\text { Panicle } \\
\text { length } \\
\text { (cm) }\end{array}$ & $\begin{array}{c}\text { Test } \\
\text { weight } \\
\text { (grams) }\end{array}$ & $\begin{array}{c}\text { Grain } \\
\text { Yield } \\
\text { (t/ha) }\end{array}$ & $\begin{array}{c}\text { Straw } \\
\text { Yield } \\
\text { (t/ha) }\end{array}$ & $\begin{array}{c}\text { Harvest } \\
\text { index }\end{array}$ \\
\hline $\begin{array}{c}\text { IR-64 } \\
\text { (Check } \\
\text { variety) }\end{array}$ & $2016-17$ & 81.9 & 19.0 & 21.7 & 23.35 & 4.51 & 5.82 & 0.44 \\
\hline & $2017-18$ & 76.2 & 18.0 & 20.8 & 23.19 & 4.33 & 6.23 & 0.41 \\
\hline Gangavathi & Average & $\mathbf{7 9 . 1}$ & $\mathbf{1 8 . 5}$ & $\mathbf{2 1 . 3}$ & $\mathbf{2 3 . 3}$ & $\mathbf{4 . 4 2}$ & $\mathbf{6 . 0 3}$ & $\mathbf{0 . 4 3}$ \\
\hline Sona & $2016-17$ & 82.0 & 24.2 & 23.9 & 24.84 & 6.27 & 7.36 & 0.46 \\
\hline & $2017-18$ & 80.5 & 22.0 & 23.2 & 23.82 & 5.62 & 6.60 & 0.46 \\
\hline & Average & $\mathbf{8 1 . 3}$ & $\mathbf{2 3 . 1}$ & $\mathbf{2 3 . 6}$ & $\mathbf{2 4 . 3}$ & $\mathbf{5 . 9 5}$ & $\mathbf{6 . 9 8}$ & $\mathbf{0 . 4 6}$ \\
\hline
\end{tabular}


Table.5 Economics of demonstrations

\begin{tabular}{|c|c|c|c|c|c|}
\hline Varieties & Year & $\begin{array}{c}\text { Gross cost } \\
\text { (Rs.) }\end{array}$ & $\begin{array}{c}\text { Gross returns } \\
\text { (Rs.) }\end{array}$ & $\begin{array}{l}\text { Net returns } \\
\text { (Rs.) }\end{array}$ & $\mathrm{BC}$ ratio \\
\hline \multirow[t]{2}{*}{ IR-64 } & $2016-17 *$ & 41000 & 69905 & 28905 & 1.71 \\
\hline & $2017-18 * *$ & 40500 & 69280 & 28780 & 1.57 \\
\hline \multicolumn{2}{|c|}{ Average } & 40750 & 69593 & 28843 & 1.64 \\
\hline \multirow{2}{*}{$\begin{array}{c}\text { Gangavathi } \\
\text { Sona }\end{array}$} & 2016-17* & 46300 & 103455 & 57155 & 2.23 \\
\hline & $2017-18 * *$ & 45600 & 89920 & 44320 & 1.97 \\
\hline \multicolumn{2}{|c|}{ Average } & 45950 & 96688 & 50738 & 2.10 \\
\hline
\end{tabular}

* - area 4 ha, 10 demonstrations

** - area 6.8 ha, 17 demonstrations

Table.6 Gap analysis

\begin{tabular}{|c|c|c|c|c|c|c|c|c|}
\hline \multirow{2}{*}{$\begin{array}{c}\text { Sl. } \\
\text { No. }\end{array}$} & \multirow[t]{2}{*}{ Year } & \multirow{2}{*}{$\begin{array}{c}\text { Area } \\
\text { (ha) }\end{array}$} & \multicolumn{3}{|c|}{ Grain yield $\left(t\right.$ ha $\left.^{-1}\right)$} & \multirow{2}{*}{$\begin{array}{c}\text { Technology } \\
\begin{array}{c}\text { gap } \\
\left(\mathbf{t ~ h a}^{-1}\right)\end{array}\end{array}$} & \multirow{2}{*}{$\begin{array}{c}\text { Extension } \\
\text { gap } \\
\left(\mathrm{t} \mathrm{ha}^{-1}\right)\end{array}$} & \multirow{2}{*}{$\begin{array}{c}\text { Technology } \\
\text { Index } \\
(\%)\end{array}$} \\
\hline & & & Potential & Demonstration & Control & & & \\
\hline 1 & 2016-17 & 4.0 & 7.5 & 6.27 & 4.51 & 1.23 & 1.76 & 16.4 \\
\hline 2 & $2017-18$ & 6.8 & 7.5 & 5.62 & 4.33 & 1.88 & 1.29 & 25.1 \\
\hline \multicolumn{3}{|c|}{ Average } & 7.5 & 5.95 & 4.42 & 1.56 & 1.53 & 20.75 \\
\hline
\end{tabular}

FLDs: During 2016-17and 2017-18, with an objective to popularise the cultivation of paddy variety GGV-05-01, the variety was up scaled from on farm testing to frontline demonstrations (FLDs) after three years of assessment and GGV-05-01 yielded 29.8 to 39 percent higher than IR 64 (5.62 to $6.27 \mathrm{t}$ $\mathrm{ha}^{-1}$, respectively for 2016-17 and 2017-18). The average yield recorded was $5.95 \mathrm{t} \mathrm{ha}^{-1}$ (34.6\% higher) and that of check variety was $4.42 \mathrm{t} \mathrm{ha}^{-1}$. The performance of GGV-05-01 with respect to other growth and yield parameters was comparably superior to the check variety. Higher plant height, number of tillers, panicle length, test weight and harvest index was recorded with GGV-05-01 (81.3 $\mathrm{cm}, 23.1,23.6 \mathrm{~cm}, 24.3 \mathrm{~g}$ and 0.46 , respectively). The straw yield was also higher than that of check variety $\left(6.98 \mathrm{t} \mathrm{ha}^{-1}\right.$ for Gangavathi Sona and $6.03 \mathrm{t} \mathrm{ha}^{-1}$ for IR 64) (Table 4). The average net returns and BC ratio were higher for GGV-05-01 (Rs. 50738 and 2.1, respectively) than IR 64 (Rs. 28843 and 1.64 , respectively) (Table 5). The variety
GGV-05-01 was found to be economical and better option to obtain higher grain yield (6). Similar findings were reported wherein it was concluded that increased yield to a greater extent can be obtained by adopting improved variety and by conducting frontline demonstrations of proven technologies (3).

Analysis of the gap showed an extension gap of 1.76 and $1.29 \mathrm{t} \mathrm{ha}^{-1}$ for 2016-17 and 201718, respectively (Table 6). This may be attributed to the adoption of recommended practices, especially the improved variety GGV-05-01 which has resulted in a better yield and returns. A technology gap of 1.23 and $1.88 \mathrm{t} \mathrm{ha}^{-1}$ for 2016-17 and 2017-18, respectively implied better performance of improved variety and more feasibility of the recommended technologies. The technology index was 16.4 and $25.1 \%$ during 2016-17 and 2017-18, respectively and the average was $20.75 \%$. Higher technology index reveals out the further need of extension services for the transfer of technology (4). 
However, the variations in the technology index may be ascribed to differences in the soil conditions, variations in environmental factors and biotic stresses.

In conclusion the performance of Gangavathi Sona in terms of yield and economics was found significantly better than the check variety giving 34.6 percent higher average yield. The frontline demonstrations proved the worthiness of the improved practices adopted, that too improved variety GGV-0501. The beneficiary farmers were the sources of the seeds and provided $1775 \mathrm{~kg}$ seeds to almost 50 ha area in other villages of the block. Hence, the dissemination of these improved technologies among the paddy growers of the region through suitable extension tools will lead to increase in the paddy yield, thereby bringing higher net returns to the farmers.

\section{References}

1. Anonymous

(2012). http://chamrajnagar.nic. in/diststat/dist_stat1.html.

2. Anonymous (2012). NBSS\&LUP, Regional Centre, Bangalore.

3. Hiremath,S.M. and Nagaraju, M. V
(2009). Evaluation of front line demonstration trials on onion in Haveri district of Karnataka. Karnataka J. Agric. Sci., 22 (5) 1092-1093.

4. Meena, M.L. and Dheeraj Singh. (2017). Technological and extension yield gaps in greengram in Pali district of Rajasthan, India. Legume Research, 40(1): 187-190.

5. Morwal, B.R., Pradeep Pagaria, B.R., Kantwa, S.L. and Shayam Das (2018). Performance of Frontline Demonstration on Yield Enhancement of Cumin in Barmer District of Rajasthan. J Krishi Vigyan 6(2): 176-178.

6. Sangeeta, Koppalkar, B.G., Desai, B.K., Satyanaranrao, Mahadev Swamy and Narayan Rao (2019). Response of rice varieties to fertilizer levels and nitrogen split applications on growth and yield of direct seeded rice. International Journal of Chemical Studies 7(1): 1622-1625.

7. Santosh, Vishwanath, J., Anand, S.R., Veeresh, H. and Balanagoudar, S.R (2019). Evaluation of Paddy (Oryza sativa L.) Varieties for Salt Tolerance in Saline Vertisols of Tungabhadra Project Command Area. Int. J. Pure App. Biosci 7(3): 149-155.

\section{How to cite this article:}

Yogesh, G. S., C. M. Sunil, A. B. Mohankumar, Chandrakala Hanagi, H. P. Rajath and Abhishek, P. S. 2020. Performance of Paddy Variety Gangavathi Sona under Kabini Command Area of Chamarajanagara District, Karnataka, India. Int.J.Curr.Microbiol.App.Sci. 9(11): 785791. doi: https://doi.org/10.20546/ijcmas.2020.911.095 